\title{
OPTIMIZATION OF CONCENTRATIONS OF PLANT GROWTH REGULATORS FOR In vitro MULTIPLE SHOOT FORMATION AND EFFICIENT ROOT INDUCTION IN Phyla nodiflora L. (Lippia nodiflora L.) AN IMPORTANT MEDICINAL PLANT RITIKA KUMARI ${ }^{\mathrm{a}}$ AND PRIYA ${ }^{\mathrm{b}}$
}

\author{
${ }^{\mathrm{ab}}$ University Department of Botany, B.R. Ambedkar Bihar University, Muzaffarpur, Bihar, India
}

\begin{abstract}
In the present study nodal and shoot tip explants were cultured in MS medium supplemented with different concentrations of BAP and KN separately, which were fortified with three different concentrations of NAA. It was noted that when nodal explants was inoculated in MS+ $2.0 \mathrm{mg} / \mathrm{l}$ BAP and $1.5 \mathrm{mg} / \mathrm{l} \mathrm{NAA}$, the percentage of response for shoot bud induction was 88.84 and the number of shoots per explants in this medium was 9.64. These were the highest percentage of response and the number shoots in this medium. In the same culture condition the percentage response for shoot tip explants was 82.26, while the number of shoots buds per explants was 7.25, respectively. When nodal explants were inoculated in MS+ $2.0 \mathrm{mg} / \mathrm{l} \mathrm{KN}+1.5 \mathrm{mg} / \mathrm{l} \mathrm{NAA}$, the percentage response for shoot bud induction was $\mathbf{7 5 . 2 5}$ and umber of shoots per explants in this medium was 6.39 , respectively. In the same medium, when the shoot tip explant was inoculated, the percentage of response for shoot bud initiation was $\mathbf{7 0 . 3 6}$ and number of shoots per explant was 4.75 respectively. It was further noted that although the above explants, also responded to other concentrations of BAP and KN, along with NAA in MS basal medium but there was discrepancy in both the percentage response as well as the number of shoot buds initiated per explants. Above in vitro raised and well grown plantlets were used for rooting. For this both $1 / 2$ strength as well $1 / 4$ strength MS basal medium were supplemented with seven different concentrations of IAA and IBA separately. Shoots were excised and inoculated in the aforesaid rooting medium. Here again it was noted that the explants inoculated in $1 / 2 \mathrm{MS}+1.0 \mathrm{mg} / \mathrm{l} \mathrm{IBA}$ revealed maximum percentage (73.54) after $36^{\text {th }}$ days of inoculation. The number of roots per explants was $34.1 / 2 \mathrm{MS}+1.0 \mathrm{mg} / \mathrm{IAA}$, induced roots and the percentage of response was 66.36, while the number of roots per explants was 2.6 only. It may be concluded that for shoot bud induction, nodal explant and MS $+2.0 \mathrm{mg} / \mathrm{l} \mathrm{BAP}+1.5 \mathrm{mg} / \mathrm{I}$ IBA was most promising culture condition. Similarly, for root induction $1 / 2 \mathrm{MS}+1.0 \mathrm{mg} / \mathrm{l}$ IBA was the best medium for Phyla nodiflora.
\end{abstract}

KEYWORDS: Nodal Explants, Shoot Bud Explants, Axillary Shoots, Regeneration, Phyla nodiflora, In vitro

ABBREVIATION: MS - Murashige \& Skoog medium, BAP- 6- Benzyl amino purine, KN- Kinetin, NAANaphthalene acetic acid, IAA- Indole acetic acid.

In spite of herbal treatments for curing different ailments from the ancient times, even today large numbers of medicinal plants are being harvested from their wild habitat. Because there is no control over their harvesting, so the agents of traders and Vaidaya, do harvest them mercilessly and due to this several species have become extinct or are on the verge of extinction. Plant tissue culture techniques are said to be more suitable alternative to help in this alarming problems. Establishment of cell, tissue and organ culture and regeneration of plantlets under in vitro conditions has opened up new avenues in the areas of plant biotechnology (Dagla, 2012). Micropropagation is the process of vegetative growth and multiplication from viable and regenerative cells in aseptic and favorable condition on suitable culture medium using various plant tissue culture techniques (Zhou and $\mathrm{Wu}, 2006$ ). Because through in vitro propagation large numbers of identical plants can be produced within a limited space and time, which can be used as planting materials, this technique is being used in the Micropropagation of different medicinal plants in and outside of our country. Phyla nodiflora L. (Lippia nodiflora L) of family Verbenaceae is found growing in different habitat under wild conditions. Plants, due to abundance of branching system form a mat where it grows. Stem reveals a runner habit with scanty roots near the nodes.

Rural people use these plants for the treatment of different diseases. The paste of stem and leaves are placed on head to cure Jaundice. This plant contains different secondary metabolites which have been isolated and identified by different workers (Ravikant et al., 2000). Modern researches have confirmed that the secondary metabolites are being used as anti-cancer, antitumor, anti-fungal and cytotoxic agents (Nishino et al., 1988). Tissue culture and micropropagation of plants have been done by Jullani et al., (1999), Lippia junelliana., Rout et al., (2000), Gupta et al., (2001), Lippia alba., Been and Martin (2003) in Ceropegia candelabrum., Bhavisha and Jasrai (2003), Arumugan et

${ }^{1}$ Corresponding author 
al., (2003), Teli and Tinko (2004), Lee (2005), Aziz et al., (2006), Zhou and Wu (2006), Arya et al., (2008), Kayo (2008), Balaraju et al., (2008), Sasikumar et al., (2009), Singh et al., (2009), Sidhu (2010), Ahmad et al., (2011), Bakrudeen et al., (2011), Parven and Shahzad (2011), Priya and Ravindra (2011), Arumugan and Gopinath (2012), Dagla (2012), Garg and Malik (2012), Thiyagrajan and Venkatachalam (2012), Vidya (2012), Balaji and Ebnezer (2013), Daksh et al., (2014), Cristiano (2015), and Kavita and Gopal (2018). Keeping the importance of this plant, present study was carried out for in vitro micropropagation of Phyla nodiflora (Lippia nodiflora $\mathrm{L}$.).

\section{MATERIALS AND METHODS}

\section{Preparation of Culture Medium}

MS basal medium was used for the present work. Above basal medium was supplemented with 3\% sucrose $(w / v)$, different concentrations of BAP and $\mathrm{KN}$ separately. Similarly, different concentrations of NAA were also added to them. The $\mathrm{pH}$ of the medium was adjusted to 5.8 , with either $1 \mathrm{~N} \mathrm{NaOH}$ or $1 \mathrm{~N} \mathrm{HCl}$, before gelling with $0.8 \%(\mathrm{w} / \mathrm{v})$ melted agar. $40 \mathrm{ml}$ of above medium was dispensed into $150 \mathrm{ml}$ conical flasks and were plugged with suitable cotton plugs, which were wrapped with Aluminum foil to prevent soaking with water vapour during sterilization at $15 \mathrm{lb}$ pressure for 25 minutes. These cultures were allowed to cool and preserved at low temperature. Inoculation was done after two days and contaminated culture flasks were discarded after autoclaving.

\section{Preparation of Explants}

Healthy branches of Phyla nodiflora were collected from the campus and brought to the laboratory immediately. Above branches were taken in $2 \mathrm{~L}$ conical flask and mouth was covered with muslin cloth with the help of rubber band.

The flask was placed under running tap water for $40 \mathrm{~min}$, so that it was washed thoroughly. Above plant materials were soaked in 5\% liquid detergent for $5 \mathrm{~min}$, and then washed under running tap water of $10 \mathrm{~min}$ so that the remains of the detergents were completely washed away. They were then treated with $0.1 \%$ systemic fungicide (Bavistin) for $10 \mathrm{~min}$ and then rinsed with sterile distilled water thrice. For further surface sterilization the explants were treated with $0.1 \%$ solution of mercuric chloride for 1.5 to $2 \mathrm{~min}$. Above explants were taken in fresh culture flask and immediately washed thoroughly with sterilized distilled water 3-4 times, so that even the traces of the chemical was removed completely. Above sterilization was done in front of running laminar air flow chamber. Above plant material was preserved in pre-sterilized and moisten muslin cloth in the aseptic condition of laminar air flow chamber.

\section{Inoculation}

From the above plant materials, nodal segments and shoot tip explants were cut and directly inoculated in the culture medium containing flasks. These flasks were incubated in the culture room, where the temperature light and humidity were maintained artificially. The temperature was adjusted at $26 \pm 1{ }^{\circ} \mathrm{C}$, moisture $66-72 \%$ and light period $16 / 8 \mathrm{~h}$ (Light and Dark) with cool white fluorescent tubes. Observation was made on an alternate day and flasks showing contamination were discarded after autoclaving. Shoots regenerated were noted and percentage response, number of shoots and shoot length were measured after certain periods. They were subcultured and well grown plantlets were inoculated in rooting medium. Here again the percentage of response for rooting was calculated. The number and length were noted. All the experiments were done in triplicate and mean of the data have been tabulated in table 1 and 2 .

Based on the above the conclusion for best plant growth regulator and its concentrations were noted.

\section{RESULTS AND DISCUSSION}

In the present work, four different concentrations of BAP and KN were supplemented separately in MS medium. Further three different concentrations of NAA were supplemented in the same medium separately. The mean of the data was taken and placed in the table 1. From the table it may be noted that highest percentages of response for axillary shoot generation was among the nodal explants inoculated in $\mathrm{MS}+2.0 \mathrm{mg} / 1 \mathrm{BAP}+1.5 \mathrm{mg} / 1 \mathrm{NAA}$ that was 88.74 . This was followed in $\mathrm{MS}+2.0 \mathrm{mg} / 1 \mathrm{BAP}+2.0 \mathrm{mg} / \mathrm{l} \mathrm{NAA}$ that was 78.34 .

Similarly, MS $+2.0 \mathrm{mg} / 1 \mathrm{BAP}+1.0 \mathrm{mg} / \mathrm{l} \mathrm{NAA}$ induced shoot buds that was 74.45. MS $+2.0 \mathrm{mg} / 1 \mathrm{KN}+$ $1.5 \mathrm{mg} / 1 \mathrm{NAA}$ induced shoot buds which was $76.25 \%$, where as $\mathrm{MS}+2.0 \mathrm{mg} / 1 \mathrm{KN}+2.0 \mathrm{mg} / 1 \mathrm{NAA}$ induced shoot buds in nodal explants that was $63.84 \%$ only. It may further be noted form the table that MS $+2.0 \mathrm{mg} / \mathrm{l}$ $\mathrm{BAP}+1.5 \mathrm{mg} / 1 \mathrm{NAA}$, induced shoot buds that was in $82.26 \%$ in shoot tip explants, which was followed by $71.86 \%$ in $\mathrm{MS}+2.0 \mathrm{mg} / \mathrm{l} \mathrm{BAP}+2.0 \mathrm{mg} / \mathrm{l} \mathrm{NAA}$. 
KUMARI AND PRIYA: OPTIMIZATION OF CONCENTRATIONS OF PLANT GROWTH REGULATORS FOR...

Percentage response for shoot bud induction was 76.25 in nodal explants when cultured in $\mathrm{MS}+2.0 \mathrm{mg} / \mathrm{KN}+1.5$ $\mathrm{mg} / 1 \mathrm{NAA}$ followed by $63.84 \%$ in $\mathrm{MS}+2.0 \mathrm{mg} / \mathrm{l} \mathrm{KN}+$ $2.0 \mathrm{mg} / 1 \mathrm{NAA}$. The percentage response for shoot bud induction on nodal explants in $\mathrm{MS}+2.0 \mathrm{mg} / \mathrm{l} \mathrm{BAP}+1.0$ $\mathrm{mg} / \mathrm{l} \mathrm{NAA}$ was 74.45 , while in $\mathrm{MS}+2.0 \mathrm{mg} / \mathrm{l} \mathrm{BAP}+1.0$ $\mathrm{mg} / 1 \mathrm{NAA}$ was 52.38 in shoot tip explants. In the similar concentration of $\mathrm{KN}+$ NAA the percentage of shoot bud induction in nodal explants was $76.25 \%$ and 63.84 , while in shoot tip explants it was 70.36 and 57.28 respectively.

Number of shoots per explant and its length were also studied. Form the table it may be noted that maximum shoot number was 9.64 among the nodal explants cultured in $\mathrm{MS}+2.0 \mathrm{mg} / \mathrm{BAP}+1.5 \mathrm{mg} / \mathrm{l} \mathrm{NAA}$, followed by 6.44 on the nodal explants cultured on MS+ $2.0 \mathrm{mg} / 1 \mathrm{BAP}+2.0 \mathrm{mg} / 1 \mathrm{NAA}$. On the similar concentration of $\mathrm{KN} \& \mathrm{NA}$, the number of shoots was 6.34 and 5.72 respectively on the nodal explants. While number of shoots in shoot tip explants was 7.25 and 6.88 in similar concentrations of BAP and NAA. In the similar concentration of KN + NAA the number shoots on shoot tip explants it was 5.75 and 3.62 respectively. Similarly, maximum length of the induced shoot was 4.62 followed by 3.54 can noted on plantlets induced form nodal explants in MS+2.0 mg/l BAP $+1.5 \mathrm{mg} / \mathrm{l} \mathrm{NAA}$ and MS $+2.0 \mathrm{mg} / 1 \mathrm{BAP}+2.0 \mathrm{mg} / 1 \mathrm{NAA}$ respectively.

Table 1: Effect of different concentrations and combination on shoot regeneration on tow explants of Phyla nodiflora, supplemented in MS medium after 56 days of inoculation

\begin{tabular}{|c|c|c|c|c|c|c|c|}
\hline \multirow{2}{*}{\multicolumn{2}{|c|}{$\begin{array}{c}\text { Plant Growth } \\
\text { Regulators (mg/l) }\end{array}$}} & \multicolumn{2}{|c|}{ Percentage of response $(\%)$} & \multicolumn{2}{|c|}{ Induction Shoot } & \multicolumn{2}{|c|}{ Shoot length $(\mathrm{cm})$} \\
\hline & & \multirow{2}{*}{$\begin{array}{c}\text { Nodal } \\
\text { explants }\end{array}$} & \multirow[t]{2}{*}{ Shoot tip } & \multirow[t]{2}{*}{ Nodal } & \multirow[t]{2}{*}{ Shoot tip } & \multirow[t]{2}{*}{ Nodal } & \multirow[t]{2}{*}{ Shoot tip } \\
\hline BAP & NAA & & & & & & \\
\hline 1.0 & \multirow{4}{*}{1.0} & 62.74 & 42.64 & 5.56 & 5.18 & 2.36 & 2.18 \\
\hline 1.5 & & 66.24 & 48.54 & 6.34 & 5.66 & 2.86 & 2.54 \\
\hline 2.0 & & 74.45 & 52.38 & 7.84 & 7.36 & 3.18 & 2.75 \\
\hline 2.5 & & 59.64 & 41.28 & 4.72 & 4.48 & 2.38 & 2.46 \\
\hline 1.0 & \multirow{4}{*}{1.5} & 64.32 & 51.46 & 6.72 & 6.36 & 2.86 & 2.68 \\
\hline 1.5 & & 76.56 & 63.88 & 7.28 & 6.84 & 3.28 & 2.88 \\
\hline 2.0 & & 88.84 & 82.26 & 9.64 & 7.25 & 4.62 & 3.4 \\
\hline 2.5 & & 61.66 & 48.76 & 5.42 & 5.12 & 2.72 & 2.16 \\
\hline 1.0 & \multirow{4}{*}{2.0} & 60.28 & 55.28 & 5.38 & 5.12 & 2.66 & 2.46 \\
\hline 1.5 & & 71.45 & 68.45 & 6.44 & 6.24 & 2.82 & 2.62 \\
\hline 2.0 & & 78.34 & 71.86 & 7.86 & 6.88 & 3.54 & 3.12 \\
\hline 2.5 & & 57.64 & 46.15 & 4.24 & 4.72 & 2.38 & 2.28 \\
\hline $\mathbf{K N}$ & NAA & & & & & & \\
\hline 1.0 & \multirow{4}{*}{1.0} & 66.54 & 65.46 & 3.24 & 3.48 & 2.68 & 2.12 \\
\hline 1.5 & & 68.72 & 67.18 & 4.58 & 4.32 & 2.88 & 2.74 \\
\hline 2.0 & & 74.36 & 68.56 & 5.44 & 4.26 & 3.36 & 3.24 \\
\hline 2.5 & & 64.28 & 56.18 & 2.84 & 3.28 & 2.24 & 1.80 \\
\hline 1.0 & \multirow{4}{*}{1.5} & 68.54 & 61.24 & 4.64 & 4.18 & 2.12 & 1.88 \\
\hline 1.5 & & 70.48 & 66.44 & 5.48 & 4.36 & 2.72 & 2.62 \\
\hline 2.0 & & 76.25 & 70.36 & 6.34 & 5.75 & 3.86 & 3.70 \\
\hline 2.5 & & 62.36 & 50.48 & 5.18 & 4.12 & 2.54 & 2.18 \\
\hline 1.0 & \multirow{4}{*}{2.0} & 46.74 & 44.66 & 3.84 & 2.54 & 1.46 & 1.28 \\
\hline 1.5 & & 54.38 & 51.42 & 4.36 & 2.24 & 1.86 & 1.42 \\
\hline 2.0 & & 63.84 & 57.28 & 5.72 & 3.62 & 2.18 & 1.78 \\
\hline 2.5 & & 51.22 & 42.16 & 3.58 & 2.45 & 1.64 & 1.22 \\
\hline
\end{tabular}

Well developed plantlets were excised from the bunch of plantlets and inoculated in rooting medium. The mean of the data obtained was placed in the table 2 . Here both $1 / 2$ strength as well as $1 / 4$ strength MS medium were supplemented with 7 different concentrations of IBA and IAA separately. Form the table it was found that maximum percentage of response 68.82 for rooting was in $1 / 2 \mathrm{MS}+1.0 \mathrm{mg} / \mathrm{lAA}$, and maximum length of the 
roots was $3.28 \mathrm{~cm}$. Similarly, the highest percentage of response for rooting was 74.54 and maximum length of the roots $5.66 \mathrm{~cm}$ in $1 / 2 \mathrm{MS}+1.0 \mathrm{mg} / 1 \mathrm{IBA}$ after 42 days of inoculation. The maximum percentage of response 64.58 and length of the roots were $3.72 \mathrm{~cm}$ in $1 / 4 \mathrm{MS}+1.0$ $\mathrm{mg} / \mathrm{l}$ IAA, while at the similar concentration of IBA percentage response for rooting was 68.54 and the number of the roots 6.4 , while the length was $5.28 \mathrm{~cm}$ respectively.
It was further noted that at both the lowest concentrations or at the highest concentrations of both the growth regulator had no promising effects on root induction. Minimum percentage of response, lowest number of roots and lesser length were fond at $0.2 \mathrm{mg} / \mathrm{l}$ of both the hormones in either $1 / 2$ or $1 / 4$ strength of MS medium.

Table 2: Effect of different concentrations of IAA and IBA supplemented in $1 / 2$ and $1 / 4$ strength of MS medium on root induction on excised plantlets of Phyla nodiflora, raised through tissue culture after 42 days of inoculation

\begin{tabular}{|c|c|c|c|c|}
\hline \multicolumn{2}{|c|}{ Growth Regulators (mg/l) } & \multirow{2}{*}{$\begin{array}{c}\text { Percentage response for } \\
\text { root induction }\end{array}$} & \multirow{2}{*}{$\begin{array}{c}\text { Number of } \\
\text { roots/plantlet }\end{array}$} & \multirow{2}{*}{$\begin{array}{c}\text { Length of roots } \\
(\mathrm{cm})\end{array}$} \\
\hline $1 / 2 \mathrm{MS}$ & IAA & & & \\
\hline & 0.2 & 46.52 & 2.46 & 1.66 \\
\hline & 0.4 & 55.78 & 2.88 & 1.84 \\
\hline & 0.6 & 61.36 & 3.54 & 2.36 \\
\hline & 0.8 & 63.24 & 3.86 & 2.74 \\
\hline & 1.0 & 68.82 & 4.62 & 3.28 \\
\hline & 1.2 & 62.44 & 3.28 & 2.78 \\
\hline & 1.4 & 41.16 & 2.74 & 2.24 \\
\hline \multirow[t]{8}{*}{$1 / 2 \mathrm{MS}$} & IBA & & & \\
\hline & 0.2 & 52.34 & 2.74 & 1.88 \\
\hline & 0.4 & 63.78 & 3.18 & 2.54 \\
\hline & 0.6 & 66.86 & 3.76 & 2.72 \\
\hline & 0.8 & 69.24 & 4.24 & 3.84 \\
\hline & 1.0 & 74.54 & 6.56 & 5.44 \\
\hline & 1.2 & 65.18 & 4.28 & 3.72 \\
\hline & 1.4 & 52.64 & 3.34 & 3.18 \\
\hline \multirow[t]{8}{*}{$1 / 4 \mathrm{MS}$} & IAA & & & \\
\hline & 0.2 & 38.28 & 2.58 & 1.84 \\
\hline & 0.4 & 46.34 & 3.16 & 2.26 \\
\hline & 0.6 & 54.68 & 3.74 & 2.78 \\
\hline & 0.8 & 59.44 & 4.36 & 3.54 \\
\hline & 1.0 & 64.58 & 5.88 & 4.68 \\
\hline & 1.2 & 50.76 & 4.66 & 3.72 \\
\hline & 1.4 & 42.24 & 3.76 & 2.88 \\
\hline \multirow[t]{8}{*}{$1 / 4 \mathrm{MS}$} & IBA & & & \\
\hline & 0.2 & 50.38 & 2.86 & 2.26 \\
\hline & 0.4 & 55.24 & 3.18 & 2.82 \\
\hline & 0.6 & 63.56 & 3.76 & 3.42 \\
\hline & 0.8 & 64.86 & 4.54 & 4.64 \\
\hline & 1.0 & 68.54 & 6.44 & 6.36 \\
\hline & 1.2 & 60.32 & 5.28 & 5.28 \\
\hline & 1.4 & 51.44 & 4.36 & 3.85 \\
\hline
\end{tabular}

\section{DISCUSSION}

From the table 1, where the percentage response for shoot bud induction, the number of shoots per explants and the length of the shoots are mentioned it appeared that shoot bud induction, in both the explants was found at all the concentrations of BAP + NAA and 
$\mathrm{KN}+\mathrm{NAA}$, but the quantum of response was different in the similar concentrations of $\mathrm{BAP}+\mathrm{NAA}$ and $\mathrm{KN}+\mathrm{NAA}$. This was also true for the number of shoot buds and their lengths. Tissue culture studies for in vitro multiple shoots induction in medicinal plants have been done by Gupta et al., (2001) in Lippia alba., Pan et al., (2003) in Artemisia and Echinops spp. Findings of these workers are in agreement with the findings of the present work. Maximum number of shoots on nodal explants of Phyla nodiflora than the shoot tip explants have been reported by Ahmad et al., (2010). The present findings corroborate with the findings of the above workers. Bhavisha and Jasrai (2010) reported that maximum number of roots were induced in plantlets of Curculigo orchioides raised through tissue culture in lowest. $1.0 \mathrm{mg} / 1$ concentrations of NAA. Whereas Sasikumar et al., (2009) reported that thick and long roots were induced in plantlets of Baliospermum montanum in MS $+1.0 \mathrm{mg} / \mathrm{l} \mathrm{IBA}$ and 0.5 $\mathrm{mg} / \mathrm{l}$ IAA. All these findings support the findings of the present works.

\section{CONCLUSION}

For multiple shoots induction in Phyla nodiflora (Lippia nodiflora) the best explants is the nodal segments. Similarly, among the plant growth regulator $\mathrm{MS}+2.0$ $\mathrm{mg} / \mathrm{l} \mathrm{BAP}+1.5 \mathrm{mg} / \mathrm{l} \mathrm{NAA}$ is the most promising culture condition for maximum multiple shoot buds induction. For rooting in the plantlets of Phyla nodiflora raised through tissue culture half strength MS $+1.0 \mathrm{mg} / \mathrm{l} \mathrm{IBA}$ was most promising condition in the present work.

\section{ACKNOWLEDGEMENT}

The authors are thankful to the Head Department of Botany, for granting permission to avail the library facilities and to work in Plant Biotechnology Laboratory of the Department.

\section{REFERENCES}

Ahmed B.A., Rao A.S., Rao M.V. and Mat Taha R., 2011. Optimization of conditions for callus induction plant regeneration and alkaloid production in stem and shoot tip explants of Phyla nodiflora. Spanish J. Agri. Res., 9(4): 1262-1270.

Arumugam A. and Gopinath K., 2012. In vitro micropropagation using corm bud explants: an endangered medicinal plant of Gloriosa superb L. Asian J. Biotech., 4(3): 120-128.
Arumugam S., Rao A.S. and Rao M.V., 2003. In vitro propagation of Aegle marmelos (L.) corr., a medicinal tree., In: Jain S.M., Ishii K. (eds) Micropropagation of woody trees and fruits. Kluwer, Dordrechet, 75: 269-315.

Arya D., Patni V. and Kant U., 2008. In vitro propagation and quercetin quantification in callus cultures of Rasna (Pluchea lanceolata Oliver \& Hiern.) Indian J. Biotechnol., 7: 383-387.

Aziz Z.A., Davey M.R., Lowe K.C. and Power J.B., 2006. Isolation and culture of protoplasts from the medicinal plant Centella asiatica. Rev. Bras. Pl. Med. Botucatu, 8: 105-109.

Bakrudeen A., Shanthi G.S., Guthaman T., Kavitha M. and Rao M., 2011. In vitro propagation of Catharanthus roseus an anti cancer medicinal plant. Acta Botanica Hungarica, 53(1-2): 197209.

Balaji P. and Ebenezer G.A.I., 2013. In vitro micropropagation of Phyla nodiflora (L) Greene a native medicinal plant. Discovery Biotechnology, 2(5): 23-28.

Balaraju K., Agastian P., Preetam Raj J.P., Arokya Raj S. and Ignacimuthu S., 2008. Micropropagation of Vitex agnus castus (Verbenacae) a valuable medicinal plant. In vitro Cell Dev. Biol. Plant, 44: 436-441.

Beena M.R. and Martin K.P., 2003. In vitro propagation of rare medicinal plant Ceropegia candelabrum L. through somatic embryogenesis. Society for in vitro Biology, 39: 510-513.

Bhavisha B.W. and Jasrai Y.T., 2003. Micropropagation of an endangered medicinal plant: Curculio orchioides Gaertn. Plant Tissue Culture, 13: 1319.

Cristiano Ferrara de Resende., Ricardo E.B., Aline M.S.O., Virginia F.B. and Paul H.P.P., 2015. In vitro propagation and acclimatization of Lippia rotundifolia, an endemic species of Brazilian campos Rupestres. Rev. Cienc. Agron., 46(3): 111.

Dagla H.R., 2012. Plant tissue culture- Historical developments and applied aspects. Resonance, 201: 759-767.

Daksh A.K., Zaid S., Suleman M., Abbas S., Wink M., 2014. In vitro propagation of the medicinal plant 
KUMARI AND PRIYA: OPTIMIZATION OF CONCENTRATIONS OF PLANT GROWTH REGULATORS FOR...

Ziziphora tenuior L., and evaluation of its antioxidant activity. S. J. Biol. Sci., 21(4): 317323.

Garg P. and Malik C.P., 2012. Multiple shoot formation and efficient root induction in Cissus quadrangularis. Int. J. of Pharmaceutical and Clinical Res., 4(1): 4-10.

Gupta S.K., Khanuja S.P.S. and Kumar S., 2001. In vitro micropropagation of Lippia alba. Current Science, 81(2): 206-210.

Jullani H.R., Korch A.R. and Tripti V.S., 1999. Micropropagation of Lippia junelliana (Mold) Tronc. Plant Cell Tissue Org. Cult., 59: 175-179.

Kavitha B. and Gopal V., 2018. In vitro micropropagation of nodal segments of Phyla nodiflora (L) Verbenaceae. Int. J. Multidiscip. Res. and Develop, 5(4): 01-04.

Kayo Y., 2008. Tissue culture of medicinal plants: Micropropagation, transformation and production of useful secondary metabolites. Studies in Natural Products Chemistry, 34: 647752 .

Lu M.C., 2005. Micropropagation of Vitis thunbergii sieb. et. Zucc., a medicinal herb through high frequency shoot tip culture. Scientia Horticulture, 107: 64-69.

Murashige T. and Skoog F.A., 1962. Revised media for rapid growth and bioassay with tobacco tissue cultures. Physiol. Plant, 15: 473-497.

Pan Z.G., Liu C.Z., Murch S.J., El-Demerdash M. and Saxena P.K., 2003. Plant regeneration from mesophyll protoplasts of the Egyptian medicinal plants, Artemisia judiica L. and Echinops spinosissimum (Turra). Plant Science, 165: 681687.

Parveen S. and Shahzad A., 2011. A micropropagation protocol for Cassia augustifolia Vahl. from root explants. Aeta Physiologiae Plantarum, 33(3): 789-796.
Priya E.S. and Ravindra R., 2011. Micropropagation of Lippia nodiflora using shoot tip and nodal explants. Int. J. of Current Res., 3(10): 43-47.

Ravikant V., Ramesh P., Diwan P.V. and Venkateswarulu Y., 2000. Helleridone and Halleron from Phyla nodiflora (L) Greene, Biochem. Syst. Ecol., 28: 905-906.

Rout G.R., Ray S.S. and Das P., 2000. In vitro manipulation and propagation of medicinal plants. Biotechnology Advances, 18: 91-120.

Sasikumar S., Raveendar S., Kumar A.P., Ignacimuthu S. and Agastian P., 2009. Micropropagation of Baliospermum montanum (willd), Mudl, Ara. A threatened medicinal plant. Ind. Journ. of Biotechnol., 8: 223-226.

Sidhu Y., 2010. In vitro micropropagation of medicinal plants by tissue culture. The Plymouth Student Scientist, 4(1): 432-449.

Singh P., Singh A., Shukla A.K., Singh L., Pande V. and Naiwal T.K., 2009. Somatic embryogenesis and in vitro regeneration of an endangered medicinal plant Sarpgandha, (Rawolfia serpentina L.). Life Scie. Journ., 6: 57-62.

Teli Nilesh P. and Timko M.P., 2004. Recent developments in the use of transgenic plants for the production of human therapeutics and biopharmaceuticals. Plant Cell, Tissue and Org. Cult., 79: 125-145.

Thiyagarajan M. and Venkatachalam P., 2012. Large scale in vitro propagation of Stevia rebaudiana for commercial application: Pharmaceutically important and antidiabetic medicinal herb. Indust. Crops and Products, 37(1): 111-117

Vidya S.M., 2012. Micropropagation of Clerodendrum serratum L. through direct and indirect organogenesis. Plant Tissue Cult. and Biotechnol., 22(2): 179-185.

Zhou L.G. and Wu J.Y., 2006. Development and application of medicinal plants tissue cultures for production of Drugs and herbal medicines in China. Natural Product Reports, 23: 789-810. 